\title{
PERANGKAT KERAS
}

\author{
MINI TINJAUAN CPU KOMPUTER SEBAGAI SALAH SATU BAGIAN \\ PENTING KOMPUTER
}

Lela Wan Cahaya PMM FITK UINSU

\begin{abstract}
ABSTRAK
Central Processing Unit atau biasanya disebut dengan Processor adalah sebuah komponen berupa chip atau IC berbentuk persegi empat yang merupakan komponen utama pada sistem komputer sebagai alat untuk menjalankan proses kinerja komputer, dengan dipadu dengan komponen lainnya. Satuan kecepatan processor ialah Mhz (Mega Heartz) atau Ghz (1000 MegaHeartz). Semakin besar nilainya, semakin cepat proses eksekusi pada komputer.

Dalam aplikasi perangkat keras komputer atau dengan istilah Hardware. Setiap komputer dibangun dengan kedalaman perangkat itu sendiri. Memiliki tingkat kecepatan yang unggul dari semua komponen komputer yang berbeda. Secara fisik, Komputer memiliki beberapa komponen yaitu sistem. Sistem adalah komponen-komponen yang saling bekerja sama membentuk suatu kesatuan. Setiap perangkat keras memiliki fungsinya masing-masing. .
\end{abstract}

Kata Kunci; Kinerja,Hardware, Keunggulan

\section{PENDAHULUAN}

Seiring dengan perkembangan zaman dan persaingan globalisasi yang terjadi menuntut setiap individu untuk memiliki kreativitas serta tekat dan semangat yang besar dalam menjalankan kehidupannya yaitu dengan menggunakan media informasi digital semacam multipedia. Salah satu teknologi yang paling canggih adalah komputer.

Pada awal mulanya penggunaan komputer berbeda dengan penggunaan komputer di era sekaranng ini. PC pada awalnya adalah sebuah mesin yang meliliki ukuran yang sangat besar sebagai ruangan yang melakukan tugas-tugas dasar seperti perkiraan sederhana. Sebagian besar sirkuit terdiri dari tabung vakum seukuran sedikit cahaya. Semikonduktor dan chip pada wafer silikon menggantikan segmen elektronik tabung vakum dengan bahaya biaya fabrikasi yang lebih rendah mendorong minat yang meluas pada PC. 
Kecepatan dalam penanganan PC terus berkembang sesuai dengan ukuran sebenarnya dari segmen ini. Kecepatan elektron yang berjalan melalui sirkuit konsisten, mengurangi ukuran sirkuit PC menjadi sebagian besar ukurannya yang unik dan bahkan beberapa juta lebih sedikit akan melipatgandakan kecepatan persiapan informasi dan mengurangi biaya fabrikasi (penurunan skala).

Di dalam PC terdapat dua gadget penting untuk membantu ukuran kerja PC. Equipment adalah gadget yang bisa dilihat dan dihubungi langsung oleh orang, sedangkan programming adalah gadget yang dapat dilihat tapi tidak bisa dihubungi langsung oleh orang. Dalam tulisan ini, pencipta akan sejenak menggambarkan salah satu gadget PC, khususnya peralatan.

Pencipta akan berbicara sejenak tentang apa yang dimaksud dengan peralatan, divisi peralatan, dan berbagai jenis peralatan di PC. Secara bahasa, perangkat PC atau biasa disebut Equipment adalah bagian PC yang dapat dilihat, dihubungi,dan dihubungi. Sebagai aturan, peralatan memiliki alas an sebagai bagian actual pada PC yang digunakan dengan kerangka kerja untuk menjalankan atau menjalankan program yang telah dikustomisasi.

Peralatan adalah bagian dari kerangka kerja gadget PC yang dapat dihubungi, dilihat secara nyata, dan dipercayakan untuk melakukan panduan dari pemrograman. Peralatan pasti dikenal sebagai peralatan PC. Peralatan PC mengasumsikan bagian yang lengkap dalam siklus kerja kerangka kerja PC. Perangkat PC dapat bekerja sesuai dengan pedoman yang telah ditetapkan di atasnya, yang pasti dikenal sebagai pedoman set. Melalui adanya amanah yang dapat dirasakan oleh peralatan tersebut, maka peralatan tersebut dapat melakukan berbagai macam latihan yang telah didiktekan oleh penyedia bearing.

Memang, PC terdiri dari beberapa segmen yang merupakan kerangka kerja. Kerangka kerja adalah bagian-bagian yang bekerja sama untuk membentuk suatu solidaritas. Jika satu bagian tidak berfungsi, itu dapat membuat siklus di PC tidak berfungsi seperti yang diharapkan. Prosesor sentral adalah perangkat gadget pada PC yang berfungsi sebagai panduan dalam hal panduan membuat program dari PC. Chip komputer juga dapat digunakan atau digunakan sebagai tempat penyimpan informasi atau dapat disebut sebagai pikiran dari semua latihan penanganan, misalnya menambah, mengatur, mencari, menyusun, membaca, dll. 


\section{STUDI LITERATUR}

Pemahaman yang lebih lengkap tentang perlengkapan PC dilakukan dari sekolah dasar hingga sekolah menengah. Pemahaman peralatan sebagai tambahan mencari tahu tentang peralatan. Pembelajaran esensial dilakukan untuk menemukan dan menumbuhkan informasi siswa tentang perangkat PC sehingga sifat imajinasi dan contoh berpikir untuk memberikan penilaian selama waktu yang dihabiskan latihan pembelajaran.

\section{METODE PENELITIAN}

Eksplorasi ini dikenang sebagai jenis penelitian lanjutan, dimana pengujian yang digunakan adalah untuk mengetahui apa saja bagian dari prosesor komputer. Strategi pengembangan yang digunakan sebagai pembantu dalam eksplorasi ini adalah teknik perbaikan media dan pengembangan pemikiran para ahli. Susunan yang dilakukan dalam pemeriksaan ini adalah pengelompokan persiapan, rencana atau rancangan dan suksesi kemajuan. Eksplorasi ini dilakukan untuk mempermudah dalam memahami dan menumbuhkan informasi agar lebih inventif, inovatif dan siap bersaing di era globalisasi. Pemahaman tentang penjelajahan ini dapat mendorong pengaturan dan bantuan yang lebih pasti. terbantu dengan media pembelajaran, khususnya penyajian modul persiapan peralatan pada PC disertai dengan contoh gambar.

\section{PEMBAHASAN}

Unit pemroses atau CPU (Central Processing Unit) merupakan alat atau unit terpenting dalam sebuah sistem komputer. Tugas utama unit pengolah adalah mampu mengelola semua sistem komputer selama proses pengolahan data. Unit pemroses sentral adalah wadah yang digunakan dalam pelaksanaan instruksi program pada komputer mikro yang dikenal sebagai mikroprosesor, prosesor ini terdiri dari ribuan dan jutaan IC. Unit pemrosesan dibagi menjadi dua bagian utama, yaitu unit kontrol dan unit aritmatika dan logika (ALU). (perangkat keras komputer, 2012).

Untuk mengetahui kegunaan dari central processing unit dan proses interaksi dengan bagian lain, kita dapat mengetahui lebih lanjut tentang proses eksekusi program. Tampilan yang paling sederhana adalah proses eksekusi program yaitu 
dengan mendapatkan directive processing yang terbagi menjadi dua langkah yaitu: operasi pembacaan perintah (fetch) dan operasi eksekusi perintah (execute).

a, Unit Catu Daya (PSU)

Catu daya menyediakan arus listrik untuk berbagai peralatan, unit pemrosesan pusat, catu daya mengubah listrik dan menyediakan aliran listrik yang stabil untuk penggunaan komputer. Kualitas catu daya menentukan kualitas kinerja komputer. Daya 300-400 watt yang disuplai oleh power supply biasanya cukup untuk sebuah komputer yang digunakan untuk mengetik atau grafis. Sedangkan daya 400-500 watt dibutuhkan jika komputer bekerja menggunakan banyak unit tambahan.

b. RAM (Random Access Memory)

RAM mewakili Memori Akses Tidak Beraturan, atau disingkat memori. Memori atau Slam adalah peralatan PC yang berharga bagi pemegang penimbunan informasi yang tidak kekal. Memori bekerja dengan menyimpan dan memberikan informasi penting yang dibutuhkan oleh Prosesor dengan cepat untuk disiapkan menjadi data. Jenis-jenis Smash adalah sebagai berikut:

\section{EDO Smash}

Slam jenis ini pertama kali ditemukan pada 72 pin dengan clock speed $50 \mathrm{MHz}$ yang sering digunakan pada Pentium 100.

\section{SDRAM (Sychronous Dynamic Arbitrary Access Memory)}

Merupakan jenis Slam yang umumnya digunakan di PC Pentium II dan III. Memiliki kecepatan 168-pin PC66, PC100, PC133।

3. DDR Smash Twofold Information Rate Irregular Access Memory.

Merupakan jenis Slam yang banyak digunakan pada Pentium IV. Memiliki 184 pin dengan kecepatan PC-1600, PC-2100, PC-2700, PC-3200, PC-3700, PC-4200.

4. DDR2 Smash Twofold Information Rate 2 Memori Akses Tidak Teratur

Adalah jenis Slam yang biasa digunakan di Pentium Double Center dan Center 2 Team. Memiliki 240 pin dengan kecepatan PC2-3200, PC2-4200, PC2-5300, PC2-6400, PC2-8500. 


\section{DDR3 Smash Twofold Information Rate 3 Memori Akses Tidak Teratur}

Adalah jenis Slam yang sering digunakan pada Pentium Quad Center, Center i3, Center i5, dan Center i7. Memiliki 240 pin dengan kecepatan PC3-6400, PC38500, PC3-10666, PC3-12800, PC3-14500, PC3-16000, PC3-17000.

\section{c. Kartu desain}

Kartu ilustrasi, atau kartu video, adalah kartu pengembangan yang berharga untuk membuat dan menampilkan tayangan layar. Kartu ilustrasi ini terdiri dari serangkaian komponen elektronik. Biasanya menghubungkan lubang pada grup utama utama dari unit persiapan fokus pada PC. Beberapa menawarkan kapasitas yang berbeda, seperti menangkap video, dan konektor untuk tuner televisi, menafsirkan MPEG-2 dan MPEG-4, FireWire, dan menghubungkan dengan berbagai tampilan. Berbagai organisasi yang memasang kartu desain peta menggabungkan ATI, Matrox, dan NVIDIA.

\section{d.Prosesor}

Prosesor, pasti sering disebut sebagai unit pengendali fokus adalah otak besar dari PC. Prosesor adalah bagian yang menjalankan total menakjubkan yang dapat memungkinkan PC digunakan untuk menjelajahi web, memutar musik di iTunes, dan menjalankan sistem kerja.

\section{e. Motherboard}

Motherboard atau Motherboard adalah papan sirkuit di mana bagian elektronik yang berbeda dihubungkan satu sama lain, motherboard sering dibatasi sebagai mobo. Pada motherboard ini, peralatan seperti hard plate, smash, prosesor, kartu desain, dan peralatan lainnya terkait. Motherboard yang sering ditemukan di pasaran saat ini adalah motherboard PC yang pertama kali dibuat berdasarkan kelayakan dengan detail IBM PC.

Inilah singkatan yang terdapat pada Motherboard:

1. $\mathrm{AGP}=$ Accelerated Graphic Por

2. $\mathrm{PCI}=$ Perpheral Component Interconect

3. $\mathrm{BIOS}=$ Basic Input Output System

4. $\mathrm{CMOS}=$ Complementary Metal Oxid Semiconductor 
5. $\mathrm{CNR}=$ Communication Network Rise

6. $\mathrm{ISA}=$ Industry Standard Architecture

7. SATA $=$ Serial Advance Technology Attachment

8. $\mathrm{IDE}=$ Integrate Drive Electronic

Yang harus diperhatikan adalah antara motherboard agar prosesor Intel dan prosesor AMD tidak setara. Karena setiap motherboard secara eksplisit ditujukan untuk prosesor tertentu. Bagian-bagian yang biasanya ditemukan pada motherboard adalah sebagai berikut:

1. Attachment Processor adalah dudukan tempat processor dipasang.

2. Pembukaan Memori adalah repositori tempat memori utama diperkenalkan

3. Northbridge, berguna untuk mengawasi lalu lintas informasi antara prosesor dan kerangka memori.

4. Southbridge, berguna untuk menghubungkan dan mengontrol sumber data, hasil setengah jalan, prosesor, Slam, menimbun gadget, dan berbagai periferal.

5. Ruang PCI Express x16, adalah celah yang dapat diperkenalkan dengan Kartu VGA zaman terbaru. 6. Ruang AGP, yaitu celah yang digunakan khusus untuk kartu VGA.

7. Baterai CMOS, yang merupakan baterai yang berharga dalam memberikan kapasitas pada Profil.

8. Port SATA, antarmuka terbaru yang dapat digunakan untuk menghubungkan Hard Circles, drive Optik dengan kerangka kerja PC.

9. Port IDE, merupakan inovasi sebelum SATA memiliki kegunaan yang serupa dengan SATA

10. Floppy Plate Port, adalah port yang digunakan untuk menghubungkan driver floppy circle ke motherboard.

11. Force port, adalah port yang digunakan untuk memberi kapasitas pada framework PC. 
Kapasitas unit penanganan fokus tergantung pada buku hariannya adalah untuk menjalankan program yang disimpan dalam memori utama dengan mengambil judul sesuai urutan baris.

Ada dua tahapan dalam penyelenggaraan mandat, secara spesifik, sebagai berikut;

1. Kegiatan pemahaman mandat

2. Aktivitas pelaksanaan perintah

Penggunaan unit persiapan fokus dilengkapi dengan mengirimkan catatan dengan adanya 44 dokumen ISO dengan ukuran catatan mutlak 25,35GB. Pengujian dilakukan di Windows 7 VM. Analisis diselesaikan beberapa kali.

\section{SISTEM PERANGKAT KERAS KELUARAN (OUTPUT DEVICE SYSTEM)}

Sebagai alat yang digunakan untuk menghasilkan akibat dari penyusunan fokus seperti desain, komposisi (huruf, angka, karakter umum, gambar, lain-lain), suara, gambar/gambar, dan struktur luar biasa yang dapat dibaca oleh mesin. Instrumen yang menunjukkan informasi yang dilakukan oleh unit persiapan fokus;

- Layar/layar/tampilkan

Layar PC adalah salah satu jenis perangkat duplikat halus, karena hasilnya adalah sebagai organisasi elektronik, untuk situasi ini gambar yang muncul di layar. Gambaran yang tampak adalah akibat dari penanganan informasi atau data info. Layar memiliki ukuran layar yang berbeda, seperti TV. Setiap merek dan ukuran layar memiliki tingkat tujuan yang berbeda. Tujuan ini dapat menentukan ketajaman gambar yang akan muncul di layar. Jenis layar saat ini sangat berubah, mulai dari ukuran besar dengan layar melengkung, hingga ukuran tipis dengan layar datar.

- Printer

Printer adalah suatu peralatan yang dihubungkan dengan PC untuk memperoleh hasil cetakan seperti komposisi atau gambar/gambar dari PC pada media kertas atau semacamnya. printer dipisahkan menjadi 3 macam, yaitu;

- Printer metrik spek,

- Printer lalat tinta, sama seperti 
- Printer aliran laser.

- $\quad$ Pembicara

Speaker disini maksudnya seperti speaker standar, speaker adalah transduser yang mengubah asosiasi listrik menjadi perulangan suara (bunyi) dengan cara menggetarkan bagiannya sebagai lapisan. Penggunaan speaker adalah untuk perangkat penghasil suara yang didapat oleh PC. Selain speaker, kami juga sering menemukan orang-orang yang menggunakan earphone/headset untuk perangkat penghasil suara.

\section{Backing Storage ( unit penyimpanan)}

Secara komperhensif unit penimbunan dapat diatur menurut ukuran kerjanya, dengan interaksi ini ada tiga kumpulan gadget kapasitas (backing stockpiling, 2010), khususnya:

- Gadget penimbunan SASD

SASD (successive access stockpiling gadget) adalah gadget berkapasitas yang bekerja secara berurutan. Gadget penimbun ini bekerja dengan membaca atau menyusun informasi secara terus-menerus dari awal hingga akhir tanpa ada kemungkinan melewatkan atau menghindari segmen tertentu. Misalnya, alat penimbun ini adalah pita atau pita yang menarik. Alat penimbunan ini biasanya panjang namun biayanya murah. Perangkat penimbunan SASD secara teratur digunakan dalam mensponsori informasi dan proyek karena informasi pendukung tidak memerlukan kecepatan tambahan.

- DASD Simpan Gadget

DASD (direct access stockpiling gadget) adalah gadget berkapasitas yang bekerja secara langsung. Gadget dapat menulis atau membaca secara alami pada wadah yang diperlukan. Misalnya, gadget ini adalah lingkaran keras, piring (Cd/DVD, lingkaran optik), dan piring floppy. Manfaat media DASD adalah siklusnya cepat, namun kekurangannya adalah biaya penjualannya terkadang masih mahal, terutama jika Anda menyertakan para sarjana dan pembaca. Streak Store Gadget Streak menimbun gadget adalah gadget sebagai chip memori, sehingga tidak membutuhkan pengembangan yang sebenarnya. Karena tidak membutuhkan pengembangan yang nyata, gadget ini dapat membaca dan menyusun informasi secara alami dan cepat. Jadi gadget ini dikenal sebagai kobaran api karena bisa dibilang secepat kilat. Sangat kontras dengan model kapasitas lainnya, gadget 
penimbun ini ukurannya lebih sederhana dan bobotnya lebih ringan. Memang, bahkan di merek-merek tertentu, sangat penting untuk menambahkan lebih banyak tidak hanya untuk menyimpan informasi, tetapi juga untuk memiliki opsi untuk memainkan melodi berbentuk MP3.

Tugas central processing unit

Unit persiapan fokus memiliki pekerjaan mengendalikan PC sehingga menyebabkan sinkronisasi kerja antar bagian dalam melakukan kapasitas kerjanya. Dalam menyelesaikan dan memahami pekerjaan sesuai dengan kapasitas dan pekerjaannya, unit penanganan fokus terdiri dari beberapa bagian yang saling berhubungan satu sama lain, terdiri dari Unit Kontrol, Unit Dasar Matematika, Register, dan Interkoneksi chip komputer.

Penanganan informasi yang masuk ke PC dan terdiri dari dua bagian;

I. Unit Cerdas Juggling Angka

II. Unit Kontrol (Unit Kontrol)

\section{A. Unit Kontrol}

Unit kontrol dapat dipercaya untuk mengambil petunjuk dari memori utama dan memutuskan jenis arah dan menangani aktivitas unit penanganan fokus seperti pada umumnya menangani PC sehingga terjadi sinkronisasi kerja antar bagian dalam melakukan kapasitas kerjanya. Kapasitas kerja adalah:

1. Kontrol dan ubah info dan hasilkan perangkat.2

2. Pulihkan mandat memori mendasar.

3. Pulihkan informasi memori dasar (jika perlu) untuk ditangani.

4. Mengirim bantalan ke ALU jika ada ekspansi matematika atau korelasi renungan dan kontrol yang dibuat oleh ALU

5. Menyimpan hasil siklus ke memori utama results

\section{B. Juggling Angka dan Satuan Alasan}

Merupakan bagian yang mampu membingkai elemen-elemen dari penyusunan informasi PC. ALU biasanya dikenal sebagai bahasa mesin karena bagian ini dapat mengeksekusi arahan bahasa mesin yang diberikan kepadanya. Serupa dengan kasus, ALU dipisahkan menjadi dua bagian, khususnya unit matematika dan unit ide boolean, yang masing-masing memiliki tugas tersendiri. Prinsip tugas 
ALU adalah melakukan semua penambahan angka (numerik) yang terjadi sesuai pedoman program. ALU memainkan semua prosedur pengurutan angka berdasarkan ekspansi hingga sirkuit elektronik yang digunakan disebut viper.

Tugas ALU berikut adalah menyelesaikan pilihan kegiatan penalaran sesuai judul program. Tugas berpikir menggabungkan korelasi dua operan menggunakan administrator berpikir tertentu, setara dengan $(=)$, tidak setara dengan, kurang atau setara dengan $(<=)$, lebih dari $(>)$, tidak persis $(<)$, dan lebih penting dari atau setara dengan $(>=)$.

\section{Register}

Register adalah media kapasitas internal unit penanganan fokus yang dapat digunakan dalam penyiapan informasi. Memori ini tidak permanen, yang secara teratur digunakan untuk menyimpan informasi saat ditangani dan informasi untuk persiapan yang dihasilkan.

\section{Interkoneksi prosesor pusat}

Interkoneksi prosesor pusat adalah kerangka kerja asosiasi dan transportasi yang menghubungkan bagian dalam chip komputer, khususnya; register, ALU, dan Control Unit seperti halnya pengangkut luar prosesor komputer yang dapat berasosiasi dengan berbagai kerangka kerja. Misalnya, memori dasar, gadget input/hasil.

\section{Komponen Amanat di Prosesor}

Pada dasarnya, kapasitas unit penanganan fokus adalah menjalankan program yang disimpan dalam memori utama dengan mengambil pedoman, mengambil arah dan menjalankannya secara individual sesuai dengan urutannya.

Untuk mendapatkan kemahiran dengan kapasitas unit penanganan fokus dan bagaimana menghubungkan dengan bagian yang berbeda, kita perlu menyelidiki ukuran pelaksanaan program. Perspektif yang paling tidak sulit dari langkah pelaksanaan program adalah mengambil penanganan mandat yang dipisahkan menjadi dua fase, yaitu:

1. Operasi baca panduan (ambil)

2. jalan menuju pelaksanaan petunjuk (eksekusi).

Bawa pesanan 
Dalam setiap pola arah, unit persiapan fokus pertama-tama akan membaca pedoman dari memori. Ada register dalam chip komputer yang berharga untuk mengontrol dan menghitung mandat berikut, yang dikenal sebagai Program Counter (PC). Penghitung Program akan memperluas pemeriksaannya satu per satu setiap kali prosesor pusat membaca mandatnya.

Perintah pembacaan dibuat dalam daftar mandat (IR). Perintah-perintah ini sebagai kode ganda yang dapat diuraikan oleh chip komputer dan kemudian memainkan aktivitas yang diperlukan. Kegiatan ini dibagi menjadi empat klasifikasi, sebagai berikut:

1. Memori prosesor komputer, informasi berpindah dari chip komputer ke memori dan sebaliknya.

2. I/O prosesor komputer, informasi berpindah dari chip komputer ke modul I/O dan sebaliknya.

3. Penyiapan informasi, prosesor pusat memainkan berbagai pemrosesan angka dan prosedur yang masuk akal pada informasi tersebut.

4. Kontrol, adalah amanat untuk mengendalikan suatu kapasitas atau pekerjaan. Seperti menyesuaikan bantalan masalah eksekusi.

\section{Mandat Eksekusi}

Bahwa siklus eksekusi untuk sebuah mandat dapat mencakup lebih dari referensi memori. Selanjutnya, pesanan dapat menentukan aktivitas I/O. Berikutnya adalah Pola Eksekusi prosesor:

1. Guidance Addess Estimation (IAC), adalah untuk menentukan atau menentukan lokasi mandat berikut yang akan dijalankan. Ini pada dasarnya termasuk menambahkan nomor tetap ke lokasi pesanan sebelumnya. Misalnya, ketika setiap

pesanan memiliki panjang 16 buah dan memori memiliki panjang 8 buah, maka pada saat itu tambahkan 2 ke alamat sebelumnya.

2. Guidance Get (IF), yaitu dengan membaca atau mendapatkan petunjuk dari area memorinya ke chip komputer

3. Guidance Activity Unraveling (IOD), yang membedah arah untuk memutuskan jenis kegiatan yang akan dilakukan dan operan yang akan digunakan.

4. Operand Address Estimation (OAC), yang mengatur lokasi operan, hal ini dilakukan bila operan tersebut menyertakan referensi operan di memori. 
5. Operand Bring (OF), yang mengambil operand dari memori atau dari modul $\mathrm{I} / \mathrm{O}$.

6. Information Activity (DO), yaitu membingkai tugas-tugas yang dikoordinasikan menuju jalur.

7. Operand store (sistem operasi), yang menyimpan konsekuensi eksekusi ke dalam memori.

\section{KESIMPULAN}

PC (peralatan) adalah salah satu bagian dari PC yang sifat-sifatnya dapat dilihat dan dihubungi secara alami atau struktur aslinya, yang berguna untuk membantu interaksi komputerisasi.

1. Chip komputer (Focal Mempersiapkan Unit) atau biasa disebut Processor adalah bagian berupa chip atau IC berbentuk persegi yang merupakan bagian dasar dari sebuah framework PC sebagai pengatur interaksi untuk eksekusi PC, dibantu oleh bagian-bagian yang berbeda.

2. Kapasitas Unit Persiapan Fokus adalah menjalankan program yang disimpan di memori utama dengan membuat langkah-langkah, menguji pedoman ini dan mengeksekusinya secara individual sesuai permintaan pesanan. Penanganan pesanan dibagi menjadi dua fase, yaitu: mendapatkan kegiatan dan menjalankan amanat.

3. Pengganggu pekerjaan utama adalah instrumen untuk mengalihkan atau menghentikan penyusunan mandat di Unit Penanganan Fokus untuk mengganggu jadwal harian. Hampir semua modul (memori dan I/O) memiliki sistem yang dapat mengganggu kerja chip komputer. 


\section{DARTAR PUSTAKA}

Yahfizham.2019.Dasar-dasar Komputer. Medan. Perdana Publishing Permana.

Budi. 2003. Perangkat Keras Komputer

Stallings, William.1998. Organisasi dan Arsitektur Komputer. Jakarta: PT Prenhallindo

Fitriyana. 2010. OrganisasiKomputer.Indraprasta

Retno. 2012. Struktur CPU Pada Komputer. Universitas Indraprasta PGRI Vol.2

Syahrul. 2010. Arsitektur OrganisasiKomputer. Andi Pubhliser.

Syahrul. 2010. Arsitektur Organisasi Komputer. Andi Pubhliser.

Putri, Nency, dkk. Aplikasi Berbasis Multimedia untuk Pembelajaran Perangkat Keras Komputer, V1.i2(70-81), Jurnal Edik Informatika. 


\section{IDENTITAS PENULIS}

Lela Wan Cahaya, saat ini mahasiswi aktif Semeser II pada Program studi S-1 Pendidikan Matematika, Fakultas Ilmu Tarbiyah dan Keguruan, Universitas Islam Negeri Sumatera Utara - Medan. 